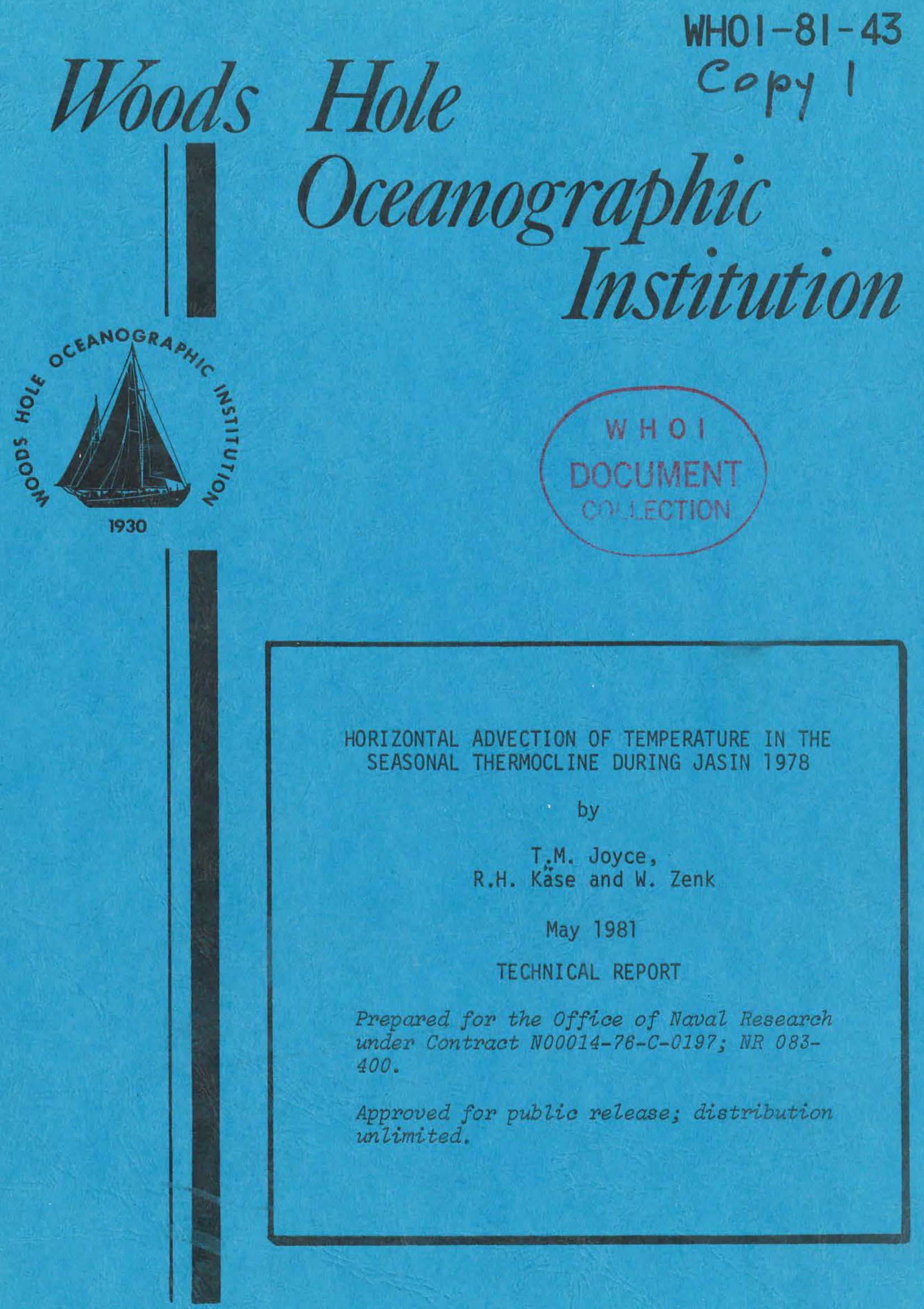

IVOODS HOLE, MASSACHUSETTS 02543 


$$
\text { WHOI }-81-43
$$

\author{
HORIZONTAL ADVECTION OF TEMPERATURE IN THE \\ SEASONAL THERMOCLINE DURING JASIN 1978
}

\author{
by
}

\author{
T.M. Joyce, \\ R.H. Käse and W. Zenk \\ WOODS HOLE OCEANOGRAPHIC INSTITUTION \\ Woods Hole, Massachusetts 02543
}

May 1981

TECHNICAL REPORT

Prepared for the Office of Naval Research under Contract N00014-76-C-0197; NR 083-400 and partial funding from the Deutsche Forschungsgemeinschaft for participation in JASIN by the computer center at Kiel University is also acknowledged.

Reproduction in whole or in part is permitted for any purpose of the United States Goverment. In citing this report in a bibliography, the reference given should be to: Joumal of Physical Oceanography 10(10): 1686-1690 (October 1980).

Approved for public release; distribution unlimited. Approved for Distribution: Valentine Worthington, Chairman Department of Physical Oceanography 
Reprinted from Journal of Physical Oceanography, Vol. 10, No. 10, October 1980 American Meteorological Society

Printed in U. S. A.

Horizontal Advection of Temperature in the Seasonal Thermocline during JASIN 1978

T. M. JoYCE

R. H. KÄSE AND W. ZENK 


\title{
Horizontal Advection of Temperature in the Seasonal Thermocline during JASIN 1978
}

\author{
T. M. JOYCE \\ Woods Hole Oceanographic Institution, Woods Hole MA 02543 \\ R. H. KÄSE AND W. ZENK \\ Institut für Meereskunde, Universität Kiel, Kiel, Federal Republic of Germany \\ 25 January 1980 and 27 June 1980
}

\begin{abstract}
The temporal changes in the low-frequency thermal structure during a two-week period in AugustSeptember 1978 are discussed from moored data collected during the JASIN experiment. While some changes in the thermal structure appear to be related to local winds, the dominant low-frequency variability in the seasonal thermocline can be explained as horizontal advection of a spatially varying temperature field, and associated thermal wind, by geostrophic currents with little vertical motion or mixing required.
\end{abstract}

\section{Introduction}

The International Joint Air-Sea Interaction study (JASIN 1978) took place north of the Rockall Trough about $450 \mathrm{~km}$ northwest of Scotland (Fig. 1). Nine nations joined for the field experiment from July to September, 1978. During two intensive observation phases up to 14 research ships and 4 research aircraft became involved. A comprehensive summary of the field phases has been made by Pollard (1978). Siedler and Zenk (1980) discuss the contributions from the Federal Republic of Germany. These include three research ships, one aircraft and three moorings consisting of self-recording current meters, thermistor chains and meteorological sensors. The intermediate mooring $\mathrm{K} 1$ with the uppermost instrument at $70 \mathrm{~m}$ depth covered the whole experiment from 9 July to 6 September. Mooring $\mathrm{K} 2$, a twofold tethered spar buoy with five Vector Averaging Current Meters (VACM) down to $110 \mathrm{~m}$, together with mooring $\mathrm{K} 3$ carrying two vertical thermistor chains, recorded only during the second field phase (25 August- 6 September). The two surface moorings $\mathrm{K} 2$, K3 were also equipped with Aanderaa wind recorders. Below we will use phase II data from three of the VACM's on K2 which were at 20,60 , and $110 \mathrm{~m}$ depth as well as the upper 14 temperature sensors on the " $B$ " chain of K3 (see Fig. 2). The data have been filtered to remove internal wave oscillations. While some changes in the thermal structure in the upper $80 \mathrm{~m}$ appear to be related to local winds, the dominant process responsible for low-frequency variability of temperature in the seasonal thermocline below the mixed layer can be identified as horizontal advection of a spatially varying temperature field.

\section{Horizontal advection of temperature}

In a technique similar to that applied to deep ocean data by Bryden (1976), we will now examine the effect of horizontal advection of temperature due to geostrophically balanced currents. Thus

$$
\left.\begin{array}{c}
\dot{T}+u T_{x}+v T_{y}=-\epsilon, \\
\rho f u_{z}=g \rho_{y} \approx-g \rho \alpha T_{y} \\
-\rho f v_{z}=g \rho_{x} \approx-g \rho \alpha T_{x}
\end{array}\right\},
$$

where $\epsilon$ represents non-modeled terms due to local heating, vertical advection and mixing. We have assumed a proportionality between temperature and density gradients. If the salinity were constant the coefficient $\alpha$ in (2) would be $0.17\left({ }^{\circ} \mathrm{C}\right)^{-1}$ for the seasonal thermocline in JASIN. An analysis of the slope of the $T / S$ curves yields a value of $0.20\left({ }^{\circ} \mathrm{C}\right)^{-1}$. This agrees with an independent estimate made for JASIN by McComas and Briscoe (1979). This approximation occasionally breaks down because of salinity-compensated intrusions and will be a source of error to be considered later.

Using the above set of equations we can obtain a relationship between the veering in the direction $\theta$ of horizontal currents with depth and the temporal changes in temperature:

$$
S^{2} \theta_{z}=g \alpha f^{-1}(T+\epsilon) .
$$


This relationship will now be used to predict changes in temperature in the seasonal thermocline and compare them with those observed during the second phase of JASIN 1978.

\section{Low-passed thermistor chain, wind and current data}

The time series from mooring $\mathrm{K} 3$ have been filtered and are shown in Fig. 3. The deepest mixed layer occurred on 23 and 24 August and can be seen as a coalescing of the temperature series at the surface on 24 August. After the wind event this mixed layer was capped by another one but can still be traced through 28 August. Other examples of new deepening events due to wind increases (e.g., 5 September) can be seen in the records.

The most striking feature in the thermocline is the oscillation in the temperature records from 28 August through 1 September. This can be traced from the deepest instrument up to $36 \mathrm{~m}$ but has no obvious surface expression. We will show that this increase on 28 August followed by a rapid decrease on 30 August is due to advection of a "front" through the moorings $\mathrm{K} 2, \mathrm{~K} 3$.

The low-frequency currents from $\mathrm{K} 2$ during phase 2 are shown in Fig. 4 in the form of a progressive vector diagram. During this period the currents at 20 and $110 \mathrm{~m}$ are largely to the southwest and parallel at both levels with the exception of 28 August when the deeper instrument veers to the left of the shallower and on 30 August when it veers to the right. One can also see that during this latter period the vertical shear is predominantly in the east-west direction.

\section{Comparison of model and data}

To illustrate the relationship in (4) we have used low-passed VACM data from K2 from 20, 60 and $110 \mathrm{~m}$ depth. The crudest approximation of (4) has been used in which the veering of the current has been estimated by differencing directions between the 20 and $110 \mathrm{~m}$ instruments, while using the speed and temperature from the $60 \mathrm{~m}$ level. This is formally valid if (4) is integrated vertically assuming speed and $T$ to be independent of depth. Our knowledge of current variations is rather limited with only three instruments, one of which is at the base of the mixed layer and may be affected by frictional, Ekman-like dynamics. The thermistor chain could be used to integrate the thermal field down to $75 \mathrm{~m}$ but not below. Reference to Fig. 4 will show that temperature changes in the seasonal thermocline are often in phase at all depths below $30 \mathrm{~m}$ with a notable exception on 1 September when temperatures are increasing below $45 \mathrm{~m}$ and decreasing above. One might anticipate our crude approximation of (4) to be violated here.

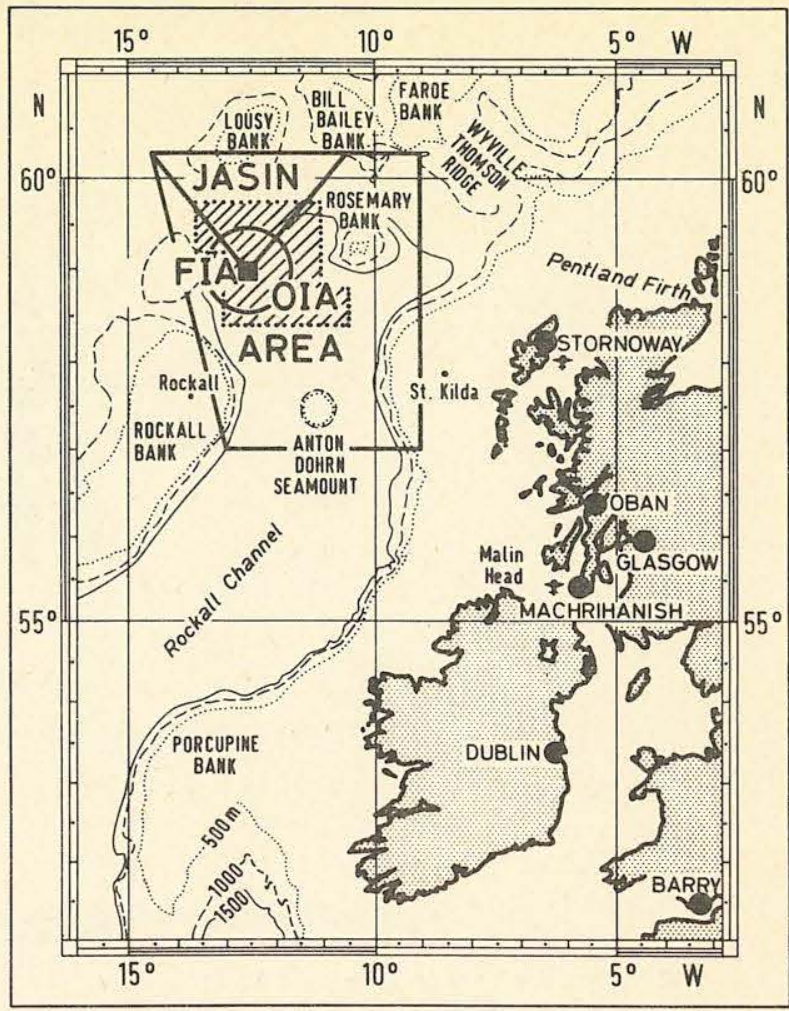

FIG. 1. Location of JASIN 1978. OIA = oceanographic intensive array, FIA = fixed intensive array. The experiment took place between 9 July and 6 September 1978 .

In Fig. 5 we show the smoothed current and temperature time series from the $60 \mathrm{~m}$ level. The temperature reaches a maximum value the day of 29 August coinciding with the time when the current begins to swing from the south toward the southwest. A comparison of the $60 \mathrm{~m}$ temperatures in Figs. 3 and 5 will show a high degree of visual correlation with no phase lag; the two moorings were separated by only $1.5 \mathrm{~km}$ with an east-west orientation. The time at which the $60 \mathrm{~m}$ current swings from the south to the southwest and back is also associated with a large turning of the current with depth and a larger-than-average magnitude of the vertical shear. This latter quantity reaches a maximum of about $1.2 \times 10^{-3} \mathrm{~s}^{-1}$ (Fig. 5, lowest panel) on 30 August. The observed and predicted rates of temperature change agree quite well during this event but diverge on 1 September. The overall correlation coefficient for these two series is 0.63 , which is barely significant at the $90 \%$ level.

\section{Discussion}

In trying to interpret the degree of correlation between horizontal advection of temperature and the observed temperature changes at a point it must be mentioned that a perfect correlation was not 

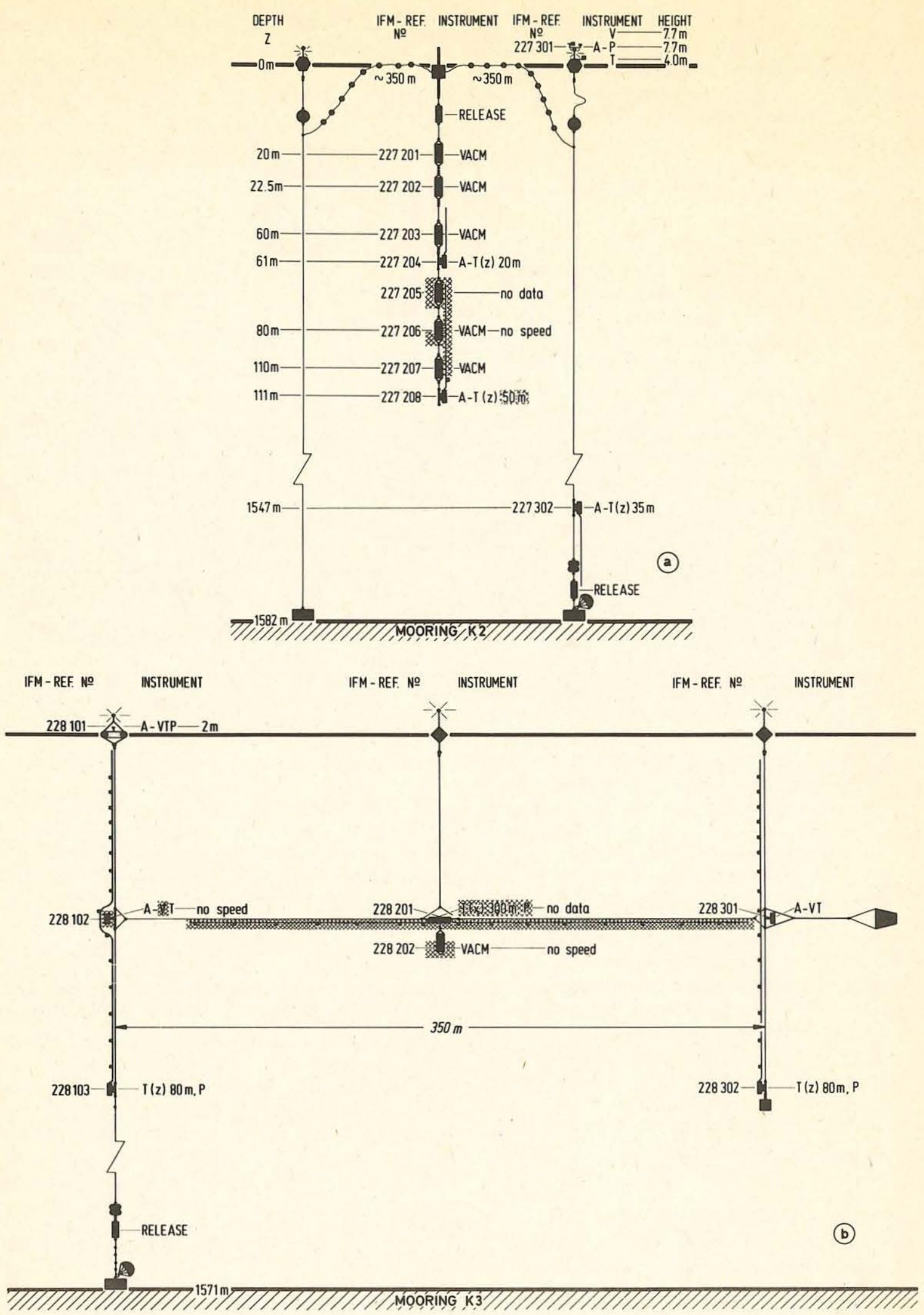

Fig. 2. JASIN moorings $\mathrm{K} 2$ (a) and $\mathrm{K} 3$ (b), two ingredients of the Fixed Intensive Array at $59^{\circ} \mathrm{N}, 12^{\circ} 30^{\prime} \mathrm{W}$. At $\mathrm{K} 2$ a $17 \mathrm{~m}$ long spar buoy served as a platform for 5 VACM's. Temperature changes at the $60 \mathrm{~m}$ level together with current shear and veering between 20 and $110 \mathrm{~m}$ are discussed in the text. The low-passed time series of the meteorological recorder on the toroid of K3 are shown in Fig. 4. The distance between the two vertical legs was $350 \mathrm{~m}$. The K2 spar buoy and the moored leg of K3 nominally were separated by $1.5 \mathrm{~km}$. 
228101

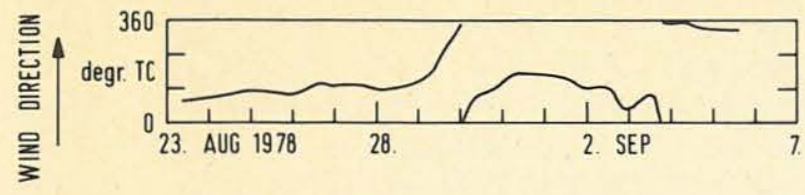

228101

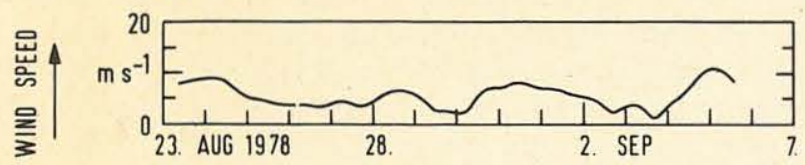

228302

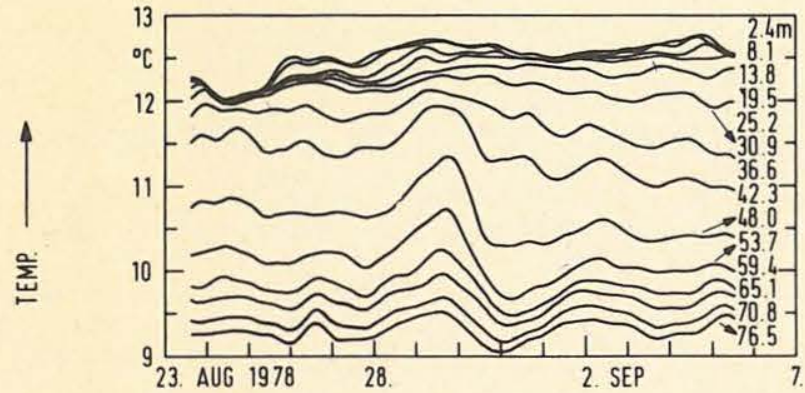

FIG. 3. Low-passed time series from mooring K3 during JASIN Phase II. Wind direction is shown in oceanographic notation (i.e., direction is that toward which wind blows).

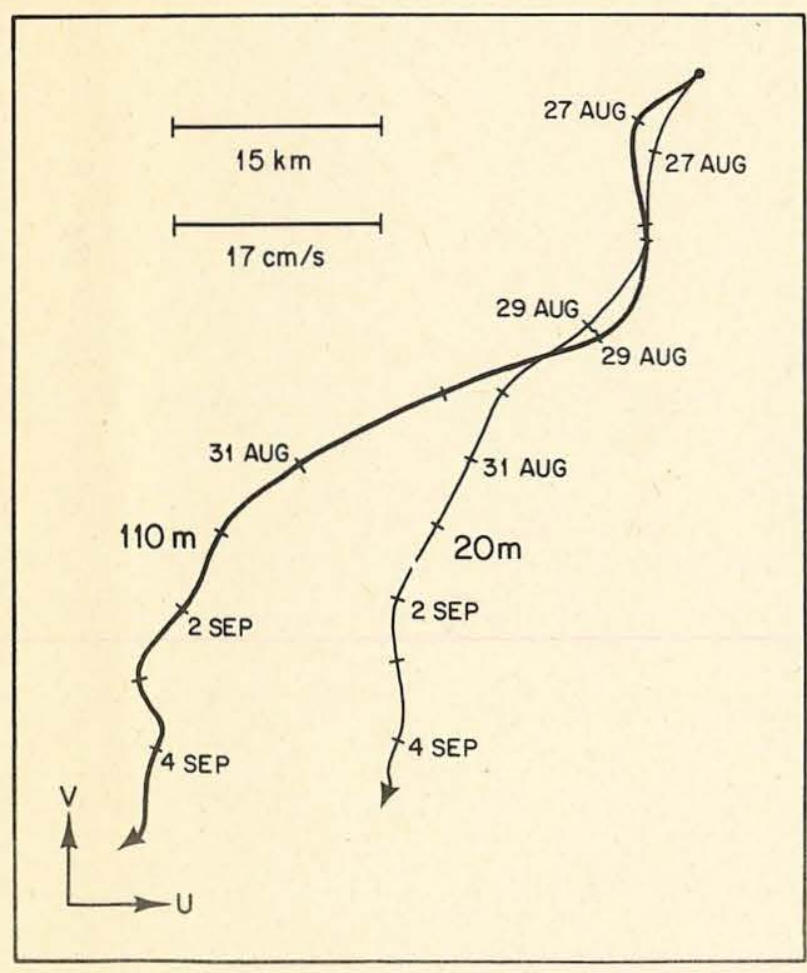

FIG. 4. Progressive vector diagram of low frequency currents at 20 and $110 \mathrm{~m}$ depth on $\mathrm{K} 2$.
227203

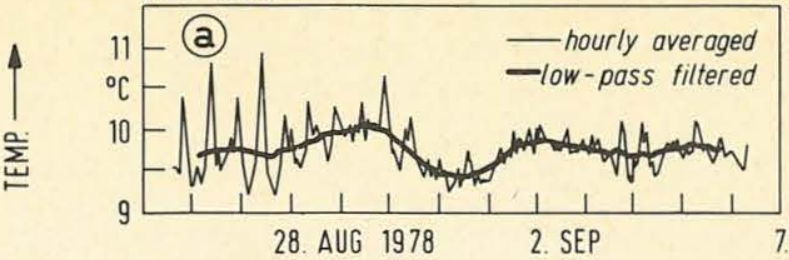

227203

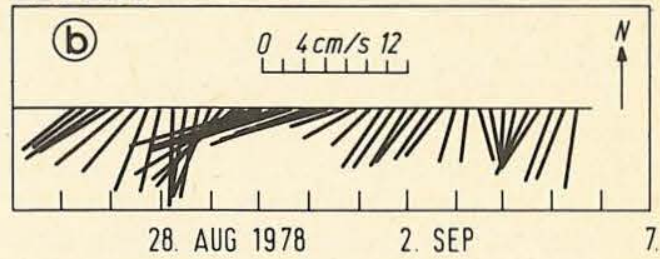

227203,228302

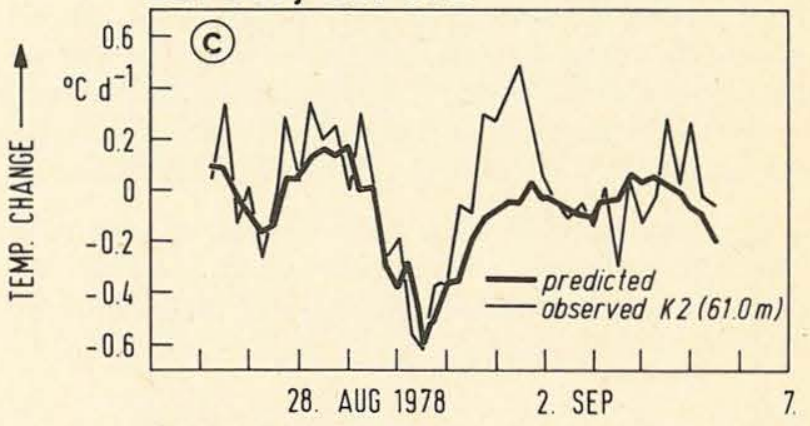

227201,227207

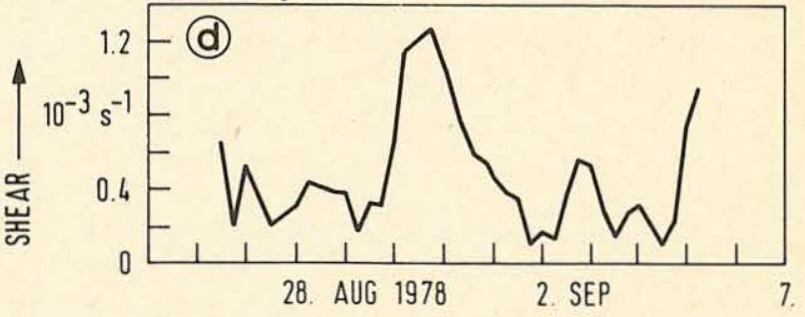

FIG. 5. Time series of VACM data from mooring $\mathrm{K} 2$, at $60 \mathrm{~m}$, during JASIN Phase II. From top to bottom: (a) temperature, (b) low-passed current vectors, (c) observed and predicted (see text) temperature changes, and (d) magnitude of vertical shear between 20 and $110 \mathrm{~m}$.

expected. One of the non-modeled terms is due to vertical advection. From the time-mean temperature profile obtained from the thermistor chain data (Fig. 3 ), we estimate a vertical temperature gradient of $\sim 0.04^{\circ} \mathrm{C} \mathrm{m}^{-1}$. In order to account for all of the difference between the observed and predicted temperature change in Fig. 5 on 1 September of $0.4^{\circ} \mathrm{C}$ day $^{-1}$, the vertical velocity would have to be $10 \mathrm{~m}$ day $^{-1}$. Preliminary estimates of wind stress curl over a JASIN meteorological triangle, $200 \mathrm{~km}$ on a side, yield vertal Ekman velocities of order $1 \mathrm{~m} \mathrm{day}^{-1}$ (Trevor Guymer, personal communication) and therefore appear inadequate to explain all of the 1 September discrepancy.

A combination of shipboard CTD surveys and 
moored data from an Aanderaa current meter with conductivity and pressure sensors at a depth of $70 \mathrm{~m}$ on $\mathrm{K} 1,1.5 \mathrm{~km}$ to the north of mooring $\mathrm{K} 2$, suggests that on 1 September a sub-surface intrusion was advected by K1. This intrusion was such that the effect of salinity variation on density nearly cancelled that of temperature, thereby violating our constant proportionality factor $\alpha$ in (4). We noted earlier that the 1 September interval was suspect because the deeper levels (Fig. 3) showed an increase in temperature, while above $45 \mathrm{~m}$ depth the temperature continued to decrease.

In order to improve quantitatively our ability to analyze the residual in (4) in terms of intrusions or vertical velocity, either the intrusions need to be averaged out by a vertical integration of (4) over a suitable depth interval or conductivity sensors must be added to moored instrumentation in the upper ocean. Nevertheless, the present data show that in the upper ocean horizontal advection of temperature is important and accounts for over $60 \%$ of the observed temperature changes during JASIN, phase 2 .

Acknowledgments. The authors wish to acknowledge the assistance and support of G. Siedler and other colleagues at the Institut für Meereskunde in Kiel for organization of the field work and col- lection of data used in this note. Thanks also go to H. Berteaux of WHOI for the design of the spar buoy and R. Pollard and M. Briscoe for helpful comments on an earlier draft of this paper. One of the authors (TJ) wishes to acknowledge a NATO Air-Sea Interaction Program travel grant while he spent six months in Kiel, as well as Office of Naval Research Contract N00014-76-C-197 NR 083-400 to the Woods Hole Oceanographic Institution. Research funds from the Deutsche Forschungsgemeinschaft for the participation in JASIN by the computer center at Kiel University are also gratefully acknowledged. This paper is WHOI Contribution 4523.

\section{REFERENCES}

Bryden, H. L., 1976: Horizontal advection of temperature for low-frequency motion. Deep-Sea Res., 23, 1165-1174.

McComas, H., and M. G. Briscoe, 1979: Buoyancy frequency near the FIA. JASIN News, No. 13 (unpublished manuscript).

Pollard, R. T., 1978: The Joint Air-Sea Interaction Experiment-JASIN 1978. Bull. Amer. Meteor. Soc., 59, 13101318.

Siedler, G., and W. Zenk, 1980: JASIN 1978, field activities on the research vessels Meteor, Planet, Poseidon and the research aircraft D-CMET. Meteor. Forschungs., A21, $25-48$. 


\section{MANDATORY DISTRIBUTION LIST \\ FOR UNCLASSIFIED TECHNICAL REPORTS, REPRINTS, AND FINAL REPORTS PUBLISHED BY OCEANOGRAPHIC CONTRACTORS \\ OF THE OCEAN SCIENCE AND TECHNOLOGY DIVISION \\ OF THE OFFICE OF NAVAL RESEARCH}

(REVISED NOVEMBER 1978)

1 Deputy Under Secretary of Defense

(Research and Advanced Technology)

Military Assistant for Environmental Science Room 30129

Washington, D.C. 20301

Office of Naval Research

800 North Quincy Street

Arlington, VA 22217

3 ATTN: Code 483

1 ATTN: Code 460

2 ATTN: 102B

1 CDR J. C. Harlett, (USN)

ONR Representative

Woods Hole Oceanographic Inst.

Woods Hole, MA 02543

Commanding officer

Naval Research Laboratory

Washington, D.C. 20375

6 ATTN: Library, Code 2627
12 Defense Documentation Center Cameron Station

Alexandria, VA 22314

ATTN: DCA

Commander

Naval Oceanographic Office

NSTL Station

Bay St. Louis, MS 39522

ATTN: Code 8100

ATTN: Code 6000

ATTN: Code 3300

1 NODC/NOAA

Code D781

Wisconsin Avenue, N.W.

Washington, D.C. 20235 
UNCLASSIFIED $5 / 81$

SECURITY CLASSIFICATION OF THIS PAGE (Whon Data Entered)

\begin{tabular}{|c|c|}
\hline REPORT DOCUMENTATION PAGE & $\begin{array}{c}\text { READ INSTRUCTIONS } \\
\text { BEFORE COMPLETING FORM }\end{array}$ \\
\hline $\begin{array}{l}\text { 1. REPORT NUMBER } \\
\qquad \text { WHOI }-81-43\end{array}$ & 3. RECIPIENT'S CATALOG NUMBER \\
\hline \multirow{2}{*}{$\begin{array}{l}\text { 4. TITLE (and Subtitle) } \\
\text { HORIZONTAL ADVECTION OF TEMPERATURE IN THE } \\
\text { SEASONAL THERMOCLINE DURING JASIN } 1978\end{array}$} & $\begin{array}{l}\text { 5. TYPE OF REPORT A PERIOD COVERED } \\
\text { Technical }\end{array}$ \\
\hline & $\begin{array}{l}\text { 6. PERFORMING ORG. REPORT NUMBER } \\
\text { WHOI cont. } 4523\end{array}$ \\
\hline $\begin{array}{l}\text { 7. AUTHOR(a) } \\
\text { T.M. Joyce, R.H. Käse and W. Zenk }\end{array}$ & $\begin{array}{l}\text { 8. CONTRACT OR GRANT NUMBER(a) } \\
\text { N00014-76-C-0197;NR 083-400 }\end{array}$ \\
\hline $\begin{array}{l}\text { 9. PERFORMING ORGANIZATION NAME AND ADDRESS } \\
\text { Woods Hole Oceanographic Institution } \\
\text { Woods Hole, Massachusetts } 02543\end{array}$ & $\begin{array}{l}\text { 10. PROGRAM ELEMENT, PROJECT, TASK } \\
\text { AREA Q WORK UNIT NUMBERS } \\
\text { NR } 083-400\end{array}$ \\
\hline \multirow{2}{*}{$\begin{array}{l}\text { 11. CONTROLLING OFFICE NAME AND ADDRESS } \\
\text { NORDA/National Space Technology Laboratory } \\
\text { Bay St. Louis, MS } 39529\end{array}$} & $\begin{array}{l}\text { 12. REPORT DATE } \\
\text { MaY }\end{array}$ \\
\hline & 13. NUMBER OF PAGES \\
\hline \multirow[t]{2}{*}{ 14. MONITORING AGENCY NAME \& ADDRESS(If different from Controlline Oflice) } & $\begin{array}{l}\text { 15. SECURITY CLASS. (of this roport) } \\
\text { Unclassified }\end{array}$ \\
\hline & $\begin{array}{l}\text { 15a. DECLASSIFICATION/DOWNGRADING } \\
\text { SCHEDULE }\end{array}$ \\
\hline
\end{tabular}

Approved for pulic release; distribution unlimited.

17. DISTRIBUTION STATEMENT (of the ebatract ontered in Block 20, if difforent from Report)

18. SUPPLEMENTARY NOTES

Reprinted from: Journal of Physical Oceanography 10(10): 1686-1690 (0ctober 1980).

19. KEY WORDS (Continuo on reverae side $/ 1$ noceseary and identtly by block number)

1. Horizontal advection of temperature

2. JASIN 1978

3. Upper ocean heat budgets

20. ABSTRACT (Continue on revereo alde if neceseary and tdentily by block number)

The temporal changes in the low-frequency thermal structure during a twoweek period in August-September 1978 are discussed from moored data collected during the JASIN experiment. While some changes in the thermal structure appear to be related to local winds, the dominant low-frequency variability in the seasonal thermocline can be explained as horizontal advection of a spatially varying temperature field, and associated thermal wind, by geostrophic currents with little vertical motion or mixing required. 


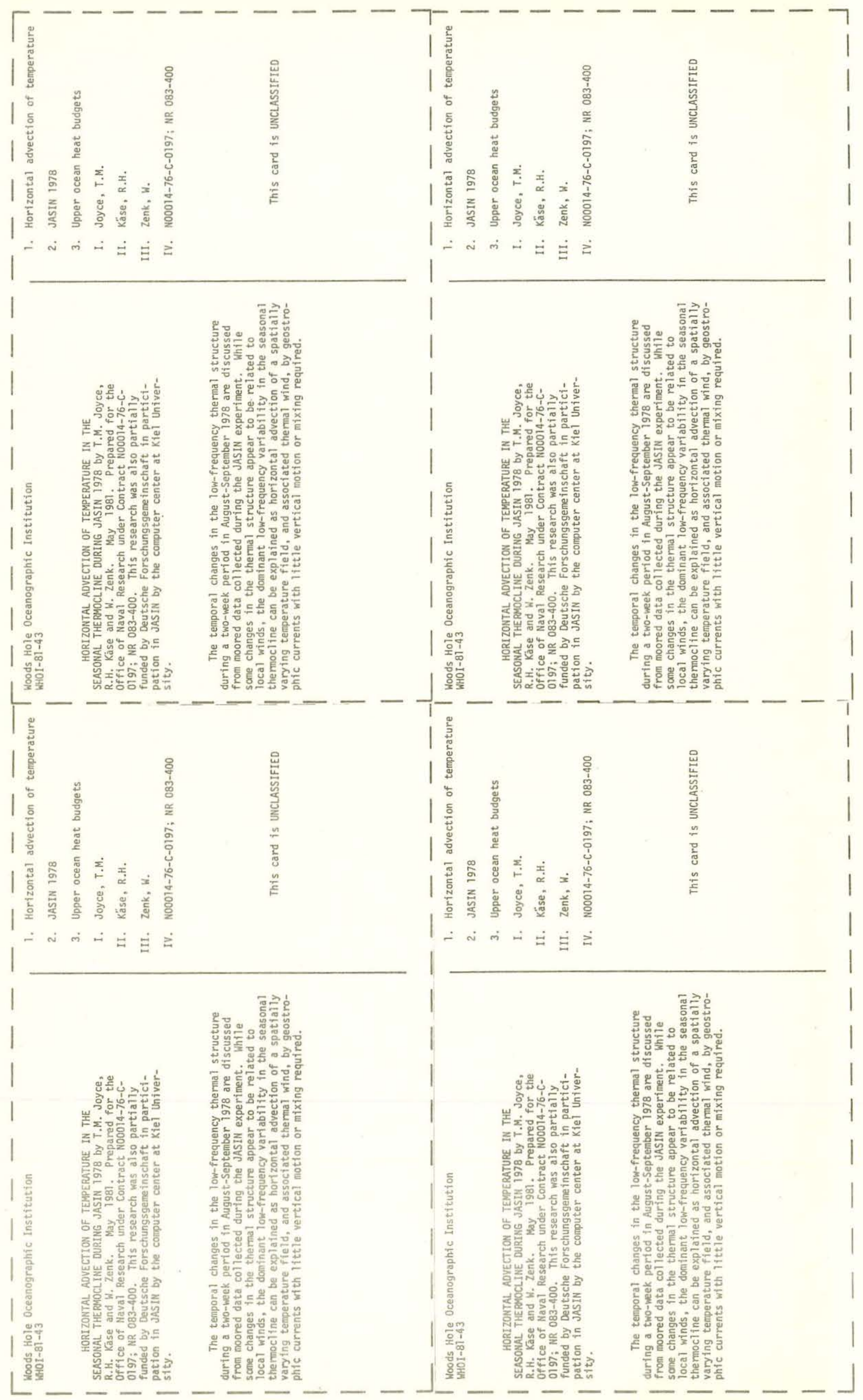

